\title{
KEBIJAKAN PEMIMPIN NEGARA \\ DALAM PERSPEKTIF KAIDAH FIKIH : Tasarruf Al-Imam Manutun Bil Maslahah
}

\author{
Achmad Musyahid Idrus* \\ * Dosen Fakultas Syariah dan Hukum UIN Alauddin Makassar \\ Email: achmad.musyahid@uin-alauddin.ac.id
}

\begin{abstract}
Abstrak
Tujuan penelitian ini untuk menemukan jawaban terhadap geneologi akar kata

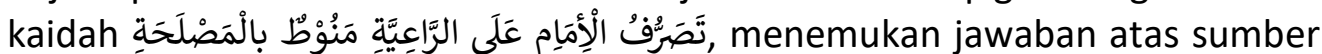
perumusan kaidah ini dan menemukan jawaban terhadap prinsip kemaslahatan yang terkandung dalam sebuah prodak perundang-undangan negara. Pendekatan normatif terhadap nas Alquran dan hadis dan hasil ijtihad ulama, pendekatan sosiologis serta pendekatan filosofis terhadap objek penelitian terkait kebijakan pemimpin negara dalam perspektif kaidah fikih

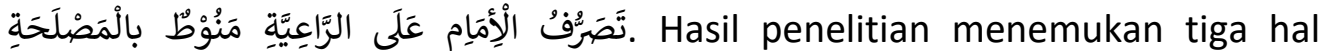
penting yaitu; 1) geneologi akar kata kaidah ini yaitu; تَصَرَُّفِ

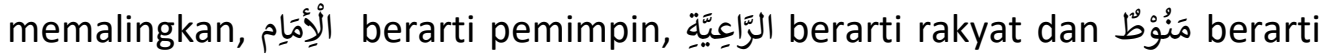
diikat serta الْمَصْلَحَحَة berarti kemaslahatan. 2) Sumber pembentukan kaidah

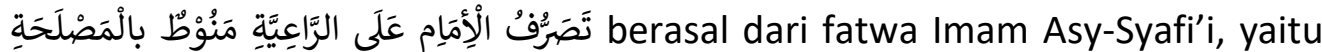

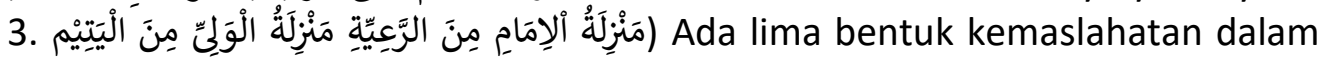

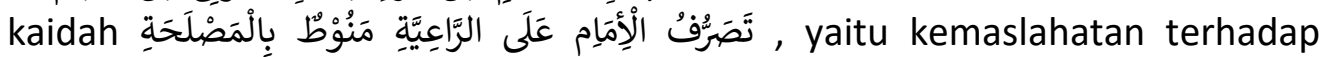
agama, kemaslahatan jiwa, kemaslahatan akal, kemaslahatan keturunan dan kemaslahatan harta.
\end{abstract}

Kata Kunci: Kebijakan; Pemimpin Negara; Tasarruf

\begin{abstract}
The purpose of this study is to find answers to the genealogy of the root of the

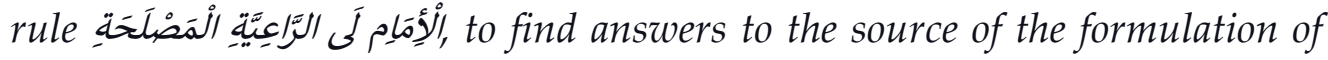
this rule and to find answers to the principles of benefit contained in a product of state legislation. A normative approach to the Qur'an and hadith and the results of ijtihad ulama, a sociological approach and a philosophical approach to the object of research related to the policies of state leaders in the perspective of figh rules الْأَمَامِ لَى الَّاعِيَّةِ الْمَصْكَة. The results of the study found three important things, namely; 1) the genealogy of the root word of this rule, namely; which means turning away, الَّلَاعِيَّة meaning meople and meaning tied up and الَْصَْحَّة meaning benefit. 2) The source of the formation of the rules

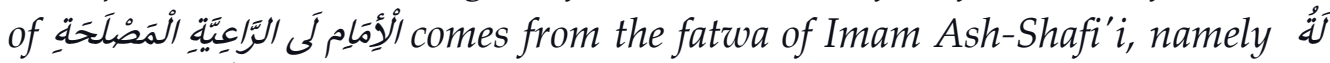
الُْوَمَامِ لَى 3 There are five forms of benefit in the rules of
\end{abstract}




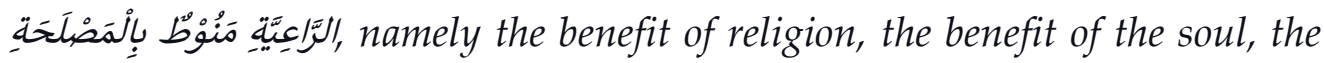
benefit of reason, the benefit of offspring and the benefit of property.

\section{Keywords: Policy; Leader of the Country; Tasarruf}

\section{PENDAHULUAN}

Kaidah fikih merupakan salah satu metode penetepan hukum dalam sisitem penemuan hukum baru dalam khazanah hukum Islam. Kaidah fikih tidak hanya berbicara tentang kaidah-kaidah pokok yang disepakati oleh para ulama tetapi kaidah fikih juga membahasa tentang persoalan-persoalan khususiyah dan persoalanpersoalan umuiyyah yang terjadi dan berkembang di tengah masyarakat islam.

Para ulama fikih memberikan perhatian yang besar terhadap persoalanpersoalan yang terkait dengan kepemimpinan dalam sebuah negara. Hukum Islam sebagai salah satu sumber penetapan hukum menjadi landasan yang kuat bagi para ulama untuk selalu menggali dan mengembangkan metode-metode ijtihadiyyah yang dapat menjadi solusi dalam menjawab persoalan-persoalan yang berkembang di kalangan masyarakat Islam.

Salah satu metode penemuan hukum yang telah dirumuskan oleh para ulama fikih adalah kaidah fikih yang membahas tentang kebijakan seorang pemimpin negara dan pemimpin masyarakat. Oleh karena kaidah ini diyakini dapat menjadi solusi yang tepat dalam membatasi bahkan meluaskan kebijakan-kebijakan seorang pemimpin yang harus diorientasikan kepada tercapainya kemaslahatan hidup setiap orang yang ditentukan nasibnya oleh seorang pemimpin negara.

Oleh karena kemaslahatan menjadi tujuan utama syariat Islam, maka mewujudkan sebuah kemaslahatan menurut kaidah ini menjadi sebuah alasan yang penting seorang pemimpin merumuskan menetapkan bahkan mengesahkan sebuah prodak perundang-undangan dalam sebuah negara. Ada lima hal penting yang menjadi tolok ukur kemaslahatan yang harus direalisasikan oleh seorang pemimpin tersebut, yaitu melindungi dan menjaga kemaslahatan agama dalam sebuh negara, melindungi dan menjaga kemaslahatan jiwa setiap warga negara, melindungi dan menjaga kemaslahatan akal manusia dari berbagai kerusakan, melindungi dan menjaga keturunan dari kepunahan serta melindungi dan menjaga harta manusia dari kerusakan.

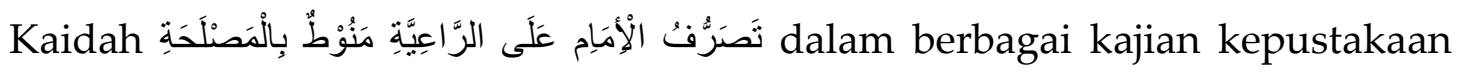
menjadi sebuah issu yang menarik untuk dikaji, oleh karena ada banyak kajian-kajian yang telah menempatkan kaidah ini dalam berbagai dialektika, namun penelitian ini sedikit berbeda dengan kajian sebelumnya di mana dalam kajian ini yang menjadi distingsi adalah kajian terhadap kebijakan seorang pemimpin dilihat dari perspektif kaidah ini.

Penelitian ini bertujuan menemukan jawaban atas tiga pertanyaan mendasar dalam kajian ini, yaitu menemukan jawaan terhadap geneologi akar kata kaidah ini, menemukan jawaban atas sumber perumusan kaidah ini dan menemukan jawaban terhadap prinsip kemaslahatan yang terkandung dalam sebuah prodak perundagundangan negara. 


\section{METODE PENELITIAN}

Metode penelitian yang digunakan dalam menganalisis permasalahan dalam penelitian ini adalah dengan melakukan penelusuran kajian pustaka berupa bukubuku referensi dan sumber-sumber hukum Islam yang relevan dengan pokok permasalahan. Pendekatan normatif terhadap nas Alquran dan hadis dan hasil ijtihad ulama, pendekatan sosiologis serta pendekatan filosofis terhadap objek penelitian

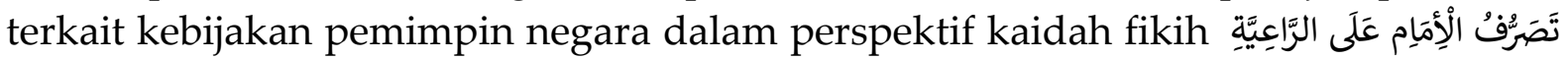
مَنْوُطٌ بِالْمَصْلَحَةِ menjawab permasalahan yang dikaji dalam penelitian ini. Dalam kajian filsafat dikenal beberapa pendekatan filosofis dalam memahami hakikat segala sesuatu terdalam dalam kehidupan ini, yaitu: Pendekatan ontologik, yaitu suatu pendekatan yang mempelajari suatu objek filsafat tertentu. Pendekatan kosmologik, mempelajari filsafat tertentu untuk mencari kebenaran segala sesuatu terdalam yang bekaitan dengan hakikat ruang, waktu dan dinamika atau gerak dari hakikat segala sesuatu itu. Pendekatan teologis, mempelajari filsafat tertentu dengan selalu mengkaitkan antara fenomena rasional, empiris dan kekuatan supra natural (Tuhan). Terakhir, pendekatan etika mempelajari filsafat tertentu dengan selalu mengkaitkan antara kajian hakikat dari segala sesuatu terdalam dengan prinsip-prinsip nilai-norma sosialbudaya yang berlaku di masyarakat. ${ }^{1}$

Sementara pendekatan sejarah sosial hukum Islam dimaksudkan dalam penelitian ini adalah mencoba mengkaji dan menganalisis perkembangan penalaran dalam hukum Islam. Sejarah sosial berasal dari dua kata yaitu sejarah dan sosial. Adapun pengertian sejarah merupakan ilmu yang mempelajari tentang peristiwa masa lampau dalam ruang dan waktu mengenai perkembangan manusia yang terdapat aktivitas manusia, sehingga mengakibatkan terjadinya perubahan pada peradaban umat manusia yang di dalamnya terdapat proses interaksi atau hubungan yang berkesinambungan antara masa lampau, masa kini dengan masa yang akan datang. Sedangkan yang dimaksud dengan Sosial dapat diartikan sebagai suatu kemasyarakatan maupaun karakteristik dari masyarakat itu sendiri. ${ }^{2}$

\section{HASIL PENELITIAN DAN PEMBAHASAN}

\section{Geneologi Makna Kaidah}

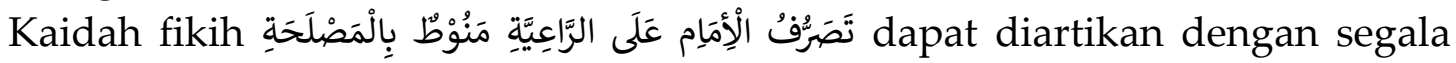
tindakan atau kebijakan seorang Imam (pemimpin) terhadap subjek maupun objek hukum yang berada di bawah kepemimpinannya, di mana kepemimpinannya tersebut harus mengacu pada terwujudnya manfaat dalam kebijakannya, baik berupa

\footnotetext{
${ }^{1}$ Ayi Sofyan, Kapita Selekta Filsafat (Cet. I; Bandung: Pustaka Setia, 2010), h. 22.
}

2Dedi Ismatullah, Sejarah Sosial Hukum (Cet. 1; Bandung: Pustaka Setia, 2011), h. 11. Lihat juga, Badri Khaeruman., Hukum Islam dalam Perubahan Sosial, Fatwa Ulama tentang Masalah-Masalah :Sosial Keagamaan, Budaya, Politik, ekonomi, Kedokteran dan HAM ( Cet. I; Bandung: Pustaka Setia, 2010), h. 5. 
manfaat duniawi maupun manfaat ukhrawi. Abdul Mujib berkata, “Tindakan dan kebijakan yang ditempuh oleh pemimpin atau penguasa harus sejalan dengan kepentingan umum bukan untuk golongan atau untuk diri sendiri."3

Kata تَصَرُفِ dalam bahasa Arab terbentuk dari kata الصرف yang berarti memalingkan." ${ }^{4}$ Di samping itu, kata ini juga memiliki makna lain seperti menukar, bertindak, bekerja dan lain-lain." ${ }^{5}$ Dan kata ini tidak memiliki penjelasan khusus secara istilah, namun ia dapat dipahami dari penggunaan orang Arab, di mana mereka menggunakan kata ini untuk menunjukkan tindakan yang dilakukan oleh seseorang baik tindakan itu berupa perkataan maupun perbuatan.

Sementara definisi الْدِمَاِمِ berasal dari kata lang berarti asal dari sesuatu. ${ }^{6}$ Kemudian setelah mengalami tashrif atau perubahan pola kata dalam bahasa Arab, terbentuklah kata الْمَمَاِم yang berarti pemimpin yang harus diikuti, ${ }^{7}$ atau bisa juga diartikan yang menjadi panutan. ${ }^{8}$ Al-Jurjani dalam bukunya yang berjudul "al-

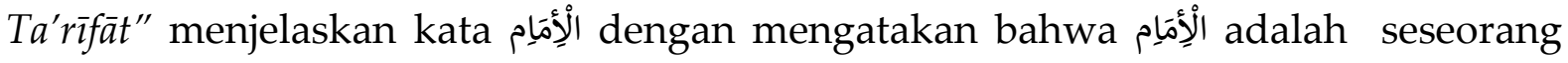
yang memegang jabatan umum dalam urusan agama dan urusan dunia sekaligus. ${ }^{9}$

Para ulama lebih banyak berbicara tentang imamah Ketika membahas masalah kepemimpinan dan masalah yang terkait dengannya, bahwa kepemimpinan itu merupakan tugas atau amanah bagi seorang pemimpin. Hal itu tentu saja sangat bisa dimaklumi, mengingat seorang imam hanyalah aktor utama dari tugas imamah yang tersebut. Di antara definisi imamah adalah apa yang disebutkan oleh Ibn Khaldun yang mengatakan bahwa imamah adalah pengganti peran dari pemilik syari'at dalam menjaga agama dan dunia. ${ }^{10}$ Imam al-Mawardi juga mengatakan bahwa imamah atau kepemimpinan adalah penggantian peran kenabian dalam menjaga agama dan dunia. ${ }^{11}$ Dalam pandangan ulama lainnya, kebanyakan dari mereka mengatakan hal yang sama tentang pengertian imamah tersebut bahwa pada intinya tugas seorang pemimpin itu adalah untuk mewujudkan dan menegakkan kemaslahatan rakyat. Definisi lain, sebagaimana yang dijelaskan oleh al-Hilli, al-Ashbahani, dan alQausyaji antara lain adalah; ${ }^{12}$

1. Seorang pemimpin adalah figur umum yang akan diikuti dan menjadi panutan

${ }^{3}$ H. Abdul Mudjib, Kaidah-Kaidah Ilmu Fikih (Jakarta: Kalam Mulia 2005), h. 61.

${ }^{4}$ Al-Thāhir Ahmadal-Zāwi, Tartib al-Qāmūs al-Muhīth 'alâ Tharīqat al-Misbāh al-Munīr wa Asās al-Balāghah (Riyādh: Dār 'Alam al-Kutub, 1996), h. 816.

${ }^{5}$ Muhammad bin Abi Bakr bin Abd al-Qādir al-Rāzi, Mukhtār al-Shihāh (Beirūt: al-Maktabah al'Ashriyyah, 2004), h. 346. dan Ibrāhīm Anîs, Abd al-Halīm Muntashir, dll., al-Mu'jam al-Wasīth, 1972, h. 538.

${ }^{6}$ Al-Rāzi, Mukhtār al-Shihāh..., h. 39.

${ }^{7}$ Al-Zāwi, al-Muhith..., h. 181.

${ }^{8}$ Al-Rāzi, Mukhtār al-Shihāh..., h. 40.

${ }_{9}^{9}$ Ali bin Muhammad bin Ali al-Jurjani, al-Ta'rīfāt (Beirut: Dār al-Kutub al-Arabi, 1405), h. 53

${ }^{10} \mathrm{Abd}$ al-Rahman bin Muhammad bin Khaldun, Muqaddimah Ibn Khaldun (Riyādh: Dār 'Alam al-Kutub, 1996), h. 337.

11‘Ali bin Muhammad bin Muhammad al-Māwardi, al-Ahkām al-Sulthāniyyah (Kairo: Dâr al-Hadīs, tt), h. 3 .

${ }^{12}$ Lihat Al-Hilli, al-Ashbahani, dan al-Qausyaji dalam Kitab Rusydi 'Ulyan, al-Islam wa al-Khilafah (Baghdād: Dār al-Salām, 1976), h. 19. 
bagi orang yang berada di bawah kepemimpinannya.

2. Ketika seorang pemimpin adalah panutan, maka ia harus bisa memberikan contoh terbaik, baik dalam menjalankan perintah maupun meninggalkan larangan, dan

3. Seorang pemimpin adalah orang yang menguasai agama sekaligus mengetahui tentang pengaturan dan tata kelola masalah kehidupan dunia.

Adapun kata الرَّاعِيَّةِ berasal dari kata رعى yang berarti menggembala, dan orang

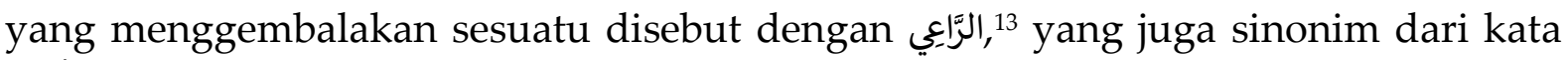

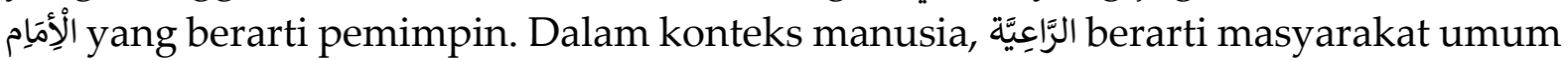
yang memiliki seorang pemimpin yang bertugas untuk mengatur segala urusan dan memperhatikan kemaslahatan mereka. ${ }^{14}$

Abd al-Karim Zaidan berkata; " $R a^{\prime}$ 'yyah adalah mereka yang berada di bawah orang-orang yang diberikan kekuasaan oleh syara' untuk memelihara dan melindungi mereka. Sehingga termasuk ke dalam makna $a l-R a^{\prime} i$ adalah penguasa dan hakim serta seluruh pemimpin dalam segala amal dan pekerjaan dan setiap orang yang memiliki kekuasaan terhadap orang lain. Oleh karena itu, siapa saja yang memegang kekuasaan atas manusia harus bertindak dengan tindakan yang dilakukan dalam rangka mewujudkan kemaslahatan buat mereka, karena ia tidak memimpin mereka dan tidak pula diberikan kekuasaan kecuali untuk melayani orang-orang yang berada di bawah kekuasaannya, menegakkan keadilan, dan berusaha untuk merealisasikan kemaslahatan serta kebaikan untuk mereka. Berdasarkan hal ini, maka tindakan seorang pemimpin (baik penguasa ataupun orang-orang yang memiliki kepemimpinan selainnya) tidak akan terwujud secara syar'i kecuali jika tujuannya adalah untuk merealisasikan kemaslahatan untuk manusia." 15

Lebih lanjut, Abd al-Karīm Zaidān dalam pernyataannya menekankan pada tiga hal pokok yang harus dilakukan oleh seorang pemimpin, yaitu: 1) Melayani orang-orang yang berada di bawah kepemimpinannya. 2) Menegakkan keadilan. 3) Merealisasikan kemaslahatan untuk manusia. Dan hal ini bisa dijadikan sebagai barometer keberhasilan sebuah kepemimpinan, yaitu jika sang pemimpin mampu melayani orang yang dipimpinnya, bisa berbuat adil dan dapat membaca serta menghasilkan kebijakan yang berpihak pada kemaslahatan rakyat atau orang yang berada di bawah kepemimpinannya, maka ia dapat dikatakan sebagai seorang pemimpin yang berhasil. ${ }^{16}$

Kata مَنْوُطْ dalam bahasa Arab berasal dari kata berarti menggantungkan, ${ }^{17}$ sehingga dari susunan kalimat dalam kaidah itu dapat dipahami bahwa makna dari kata مَنْوُط yaitu adanya keterikatan atau ketergantungan dari sebuah tindakan atau kebijakan seorang pemimpin dengan kemaslahatan bagi orang yang berada di bawah kepemimpinannya.

\footnotetext{
${ }^{13}$ Ibrāhīm..., al-Mu'jam, h. 380.

${ }^{14}$ Ibrāhīm..., h. 380.

${ }^{15} \mathrm{Abd}$ al-Karīm Zaidān, al-Wajīz fì Syarh al-Qawā'id al-Fiqhiyyah (Beirūt: Muassasah al-Risālah, 2004), h.122.

16Zaidān..., h. 122.

17Ibrāhīm, Mu'jam..., h. 1004.
} 
Adapun makna kata صَصْلَحَة berasal dari kata صلح - يصلح yang kemudian

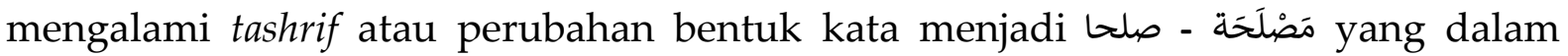
bahasa Arab memiliki arti tidak memiliki bahaya, atau dapajuga bermakna lawan dari bahaya. ${ }^{18}$ Secara istilah, ada beberapa definisi yang disebutkan oleh para ulama tentang maslahah, antara lain dikemukakan oleh Imam al-Ghazali misalnya ia mengatakan bahwa maslahat adalah menjaga maqâshid syari'ah atau apa yang menjadi tujuan dari adanya syari'ah. Ia menambahkan bahwa maqâshid syari'ah atas manusia ada lima, yaitu menjaga agama, jiwa, akal, nasab, keturunan, dan harta mereka; sehingga segala yang mengandung penjagaan terhadap lima hal pokok ini adalah maslahat, dan segala yang mengabaikan masalah pokok ini adalah mafsadah serta menolak atau menghilangkannya adalah bagian dari maslahat. ${ }^{19}$ Di samping alGhazāli, al-Khawarizmi juga memberikan definisi tentang maslahat dengan mengatakan bahwa yang dimaksud dengan maslahat adalah memelihara maqāshid al-Syarīah dengan menghindarkan mafsadah (kerusakan) pada manusia. ${ }^{20}$

\section{Sumber Perumusan Kaidah}

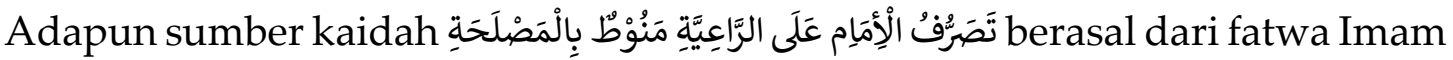

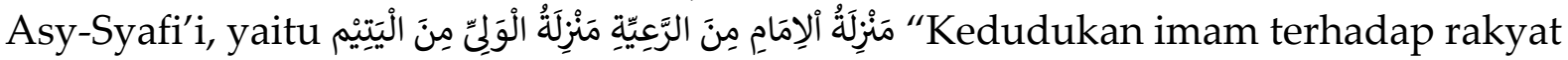
adalah seperti kedudukan wali terhadap anak yatim". Menurut Imam Syafi'i, fatwa tersebut berasal dari fatwa Umar bin Khattab yang diriwayatkan oleh Sa'id bin Mansyur dari Abu Ahwash dari Abi Ishaq dari Barra' bin Azib, yang berbunyi;

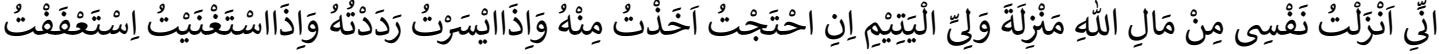

\section{Terjemahnya:}

"sungguh aku menempatkan diriku terhadap harta Allah seperti kedudukan wali terhadap anak yatim, jika aku membutuhkan, aku mengambil dari padanya, dan apabila ada sisa aku kembalikan. Dan apabila aku tidak membutuhkan, aku menjauhinya (menahan diri padanya)". ${ }^{21}$

Dari perkataan Umar bin Khattab di atas dapat dipahami bahwa seorang wali dari anak yatim memiliki hak penuh terhadap anak yatim tersebut, apakah si wali tersebut akan mengambil hartanya lalu dimanfaatkan atau tidak mengambil apapun jika memang si wali tidak maka. Atas dasar itu, maka seorang pemimpin memiliki hak penuh terhadap rakyatnya, maka seorang pemimpin memiliki kewajiban membawa rakyatnya kepada kedamaian dan dalam memerintah dengan mengedepankan kemaslahatan rakyat. Hal ini juga ditegaskan oleh Nabi Saw., dalam salah satu haditsnya yang menegaskan bahwa tiap-tiap manusia itu memimpin

\footnotetext{
${ }^{18}$ Ibrāhīm..., h. 545. Lihat juga, Al-Muhīth..., h. 839; Ibn al-Mandzūr, Lisān al-'Arab al-Muhith (Beirūt: Dār Lisān al-'Arab, tt), h. 462; Al-Rāzi..., h. 351.

${ }^{19}$ Muhammad bin Muhammad al-Ghazāli, al Mustashfā fì Ushūl al-Figh (Beirūt: Muassasah al-Risālah, 1997), h. 378-379.

${ }^{20}$ Muhammad bin 'Ali al-Syaukāni, Irsyād al-Fuhūl Ilā Tahqīq al-Haq min 'Ilm al-Ushūl (Riyādh: Dār alFadhīlah, 2000), h. 990.

${ }^{21}$ Mudjib, Kaidah..., h. 61-62

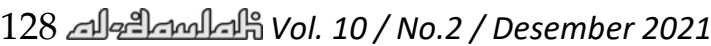


dirinya sendiri dan orang lain dan akan dimintai pertanggung jawaba atas kepemimpinannya. Begitu juga dengan seorang presiden ataupun khalifah menjadi pemimpin bagi rakyatnya dan akan dimintai pertanggung jawaban dari apa yang dipimpinnya. ${ }^{22}$

Terjemahnya:

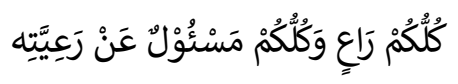

"Masing-masing kalian adalah pemimpin, dan setiap pemimpin akan dimintai pertanggung jawaban atas kepemimpinannya."

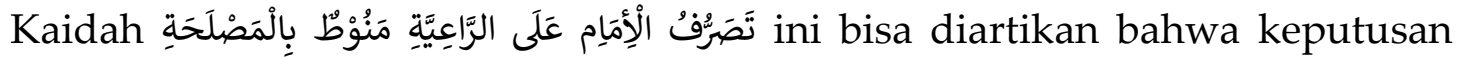
seorang pemimpin suatu pemerintahan haruslah selalu berorientasikan kepada kebaikan masyarakat karena seorang pemimpin merupakan orang yang memiliki kekuasaan terhadap yang dipimpinnya. Salah satu bentuk kekuasaan yang diperoleh oleh seorang pemimpin adalah memutuskan suatu perkara atau menentukan sebuah kebijakan. Jika kita berpegang kepada kaidah di atas, maka apa yang akan diputuskan oleh seorang pemimpin atau kebijakan apa yang akan diambil haruslah memiliki orientasi yang baik, yang membawa kemashlahatan kepada yang dipimpinnya. Kaidah ini juga diperkuat dengan QS. An-nisa ayat 58 yang berbunyi;

Terjemahnya :

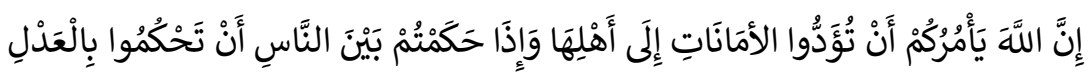

"Sesungguhnya Allah menyuruh kamu menyampaikan amanat kepada yang berhak menerimanya, dan (menyuruh kamu) apabila menetapkan hukum di antara manusia supaya kamu menetapkan dengan adil."

Sebagaimana telah dijelaskan di atas bahwa kaidah ini merupakan kaidah fikih yang mempunyai aspek horizontal, karena dalam implementasinya memerlukan hubungan antara seorang pemimpin dengan masyarakat atau rakyat yang dipimpin. Lebih jauh dari sekedar pengetian retorik tersebut, maka ada pengertian yang lebih luas adalah segala aspek kehidupan yang meliputi kepentingan rakyat dalam suatu kelompok atau golongan tertentu harus ditetapkan dengan mekanisme musyawarah. Hal ini sebagai terjemahan dari pernyataan kaidah tersebut yang menekankan pada aspek kemaslahatan, karena metode musyawarah adalah salah satu bentu yang riil untuk mencapai dan medapatkan suatu kemaslahatan untuk bersama. Hal ini yang juga ditekankan dalam firman Allah QS. As Syura ayat 38 yang berbunyi;

Terjemahnya :

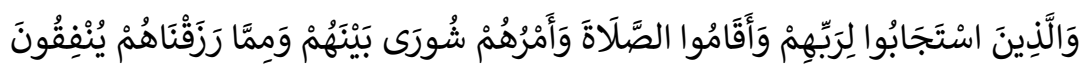

Dan (bagi) orang-orang yang menerima (mematuhi) seruan Tuhannya dan mendirikan shalat, sedang urusan mereka (diputuskan) dengan musyawarah antara mereka; dan mereka menafkahkan sebagian dari rezki yang kami berikan kepada mereka.

\footnotetext{
${ }^{22}$ Muchlis Usman. MA, Kaidah-Kaidah Istinbath Hukum Islam (kaidah-kaidah ushuliyah dan fikihiyah) (Jakarta: PT Raja Grafindo Persada,2002), h.144.
} 


\section{Prinsip Kemaslahatan dalam Prodak Perundang-Undangan Negara}

Prinsip kemaslahatan harus ada dalam sebuah prodak perundang-undangan yang dirumuskan oleh pemerintan oleh karena kemaslahatan manusia merupakan hak azasi yang yang harus diwujudkan dalam kehidupan setiap masyarakat. Prinsipkemaslahatan ini dapat ditemukan di dalam Alquran maupun dalam sejarah Islam. Hal ini dimaksudkan untuk menyelaraskan ketetapan-ketetapan hukum yang ditetapkan oleh pemerintah harus sejalan dengam kepentingan dan kemaslahatan manusia yang harus tetap dilindungi.

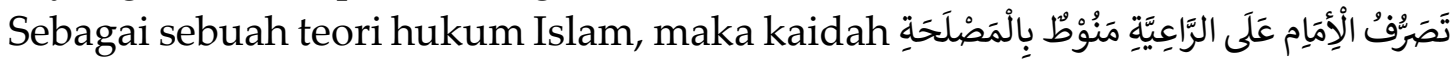
senantiasa memperhatikan berbagai kemaslahatan masyarakat. Jika kemaslahatan itu bertentangan dengan satu sama lain, maka didahulukan kemaslahatan umum dari kemaslahatan pribadi dan diharuskan menolak kemudaratan yang lebih besar dengan jalan meninggalkan dan melaksanakan yang lebih sedikit mudaratnya. ${ }^{23}$

Mewujudkan kemaslahatan manusia adalah tujuan utama yang terkandung dalam kaidah تَصَرُفُ الْدِمَامِ عَلَى الرَّاعِيَّة مَنْوُط بِالْمَصْلَحَةِ Setidaknya ada dua hal yang menjadi inti dari kemaslahatan yang terkandung dalam kaidah ini, yaitu pencapaian dalam menarik kemanfaatan dan mencegah kemudaratan. ${ }^{24}$ Perbuatan masyarakat akan memiliki nilai jika mengarah kepada upaya dengan sadar untuk menemukan kebaikan dibalik proses menarik manfaat dan menghindari keburukan dalam proses menghindari kerusakan. ${ }^{25}$

Kemasalahatan pokok mencakup lima hal (al-kulliyat al-khams) yang dipandang oleh para ulama sebagai landasan dasar tujuan syariat yang harus dijaga. Kelima landasan dasar itu adalah perlindungan terhadap agama, perlindungan terhadap jiwa, perlindungan terhadap akal, perlindungan terhadap keturunan dan perlindungan terhadap harta. ${ }^{26}$

Perbuatan hukum masyarakat selanjutnya dihadapkan pada sejauh mana tindakan tersebut dapat berafiliasi dengan kelima hal yang dianggap paling sakral dan sangat dilindungi dalam kehidupan masyarakat, itulah sebabnya semua bentuk peraturan perundang-undangan yang dirumuskan oleh seorang pemimpin harus berlandaskan pada kelima bentuk kemaslahatan tersebut, yaitu mewujudkan kemaslahatan agama, mewujudkan kemaslahatan jiwa, mewujukan kemaslahatan akal, mewujudkan kemaslahatan keturunan dan mewujudkan kemaslahatan harta.

Karena itu, seorang pemimpin harus bisa menjaga dan melindungi kemaslahatan agama dalam bernegara. Dengan kata lain, seorang pemimpin negara tidak boleh memaksakan sebuah agama tertentu oleh karena pemaksaan agama

\footnotetext{
${ }^{23}$ Umar Shihab, Kontekstualitas Al-Qur'an, Kajian Tematik Atas Ayat-Ayat Hukum dalam Alquran (Cet; ke3; Jakarta: Piramida, 2005), h. 216-217.

${ }^{24} \mathrm{Al}-\mathrm{Syāatibī,} \mathrm{Abu} \mathrm{Ishaq.} \mathrm{al-Muwā̄aqāat} \mathrm{fì} \mathrm{Ușūl} \mathrm{al-Syarī'ah} \mathrm{(Juz} \mathrm{II;} \mathrm{Beirut:} \mathrm{Dār} \mathrm{al-Ma'rifah,} \mathrm{t.th),} \mathrm{h.} 13$.

${ }^{25}$ TM. Hasbi Ash Shiddieqy, Falsafah Hukum Islam (Jakarta: Bulan Bintang, 1975), h. 186-187

${ }^{26}$ Muhammad Amin bin Muhammad Mukhtar al-Juknīy al-Syanqițīy, al-Mașālih al-Mursalah (Saudi Arabiyah; Al-Jāmi' ah al-Madinah al-Munawwarah, 1410 H.), h. 4
} 
secara jelas dapat diartikan bahwa agama adalah sesuatu yang urgen, maka tidak ada paksaan di dalamnya, begitupula untuk memeluknya, sebagaimana ayat dalam QS Yunus/10; 99.

Terjemahnya :

Dan jikalau Tuhanmu menghendaki, tentulah beriman semua orang yang di muka bumi seluruhnya. Maka Apakah kamu (hendak) memaksa manusia supaya mereka menjadi orang-orang yang beriman semuanya. ${ }^{27}$

Sebagai seorang pemimpin negara, nabi telah mengatur dengan baik kemaslahatan antar agama dengan membiarkan non muslim melaksanakan ibadah mereka di masjid rasul tatkala rasul akan menerima mereka dan waktu ashar telah masuk. Mereka kemudian berdiri melaksanakan sembahyang ala mereka dengan menghadap ke timur. Rasulullah kemudian membiarkan non muslim tersebut dan melarang sahabat untuk mencegahnya. ${ }^{28}$

Dengan kata lain, mewujudkan kemaslahatan dalam agama merupakan sesuatu yang tidak bisa diabaikan oleh setiap warga negara, khususnya yang seseorang yang beragama Islam oleh karena Allah memerintahkan manusia untuk memiliki rukun iman yang enam, mengerjakan dasar-dasar ibadah seperti salat dan puasa. Selain itu untuk menjaga kemaslahatan yang berkenaan dengan agama Allah melarang manusia berbuat murtad (keluar dari agama Islam). Karena hal itu akan mencederai kemaslahatan manusia yang berbentuk agama, sebagaimana dalam QS. al-Taubah/9: 41:

Terjemahnya:

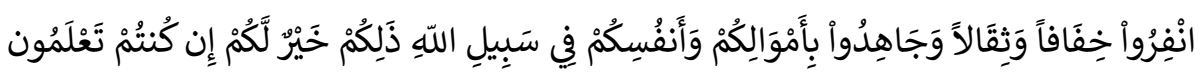

"Berangkatlah kamu baik dalam keadaan merasa ringan ataupun merasa berat, dan berjihadlah dengan harta dan dirimu di jalan Allah. Yang demikian itu adalah lebih baik bagimu jika kamu mengetahui." 29

Untuk perlindungan terhadapjiwa, seorang pemimpin negara harus menjamin dan memberikan perlindungan terhadap jiwa masyarakat, mulai dari pengaturan hukum seputar menggugurkan janin atau aborsi, aturan hukum membunuh orangorang kafir zimmi sampat pada pengaharaman pembunuhan secara umum. Atas dasar perlindungan terhadap jiwa, maka perbuatan masyarakat dalam hal pembunuhan dikategorisasi menjadi 3 bagian besar, yaitu pembunuhan sengaja, pembunuhan semi sengaja dan pembunuhan karena khața atau kesalahan. Seluruh bentuk perbuatan membunuh ini akan mendapatkan ganjaran, mulai dari yang terkecil hingga terbesar yaitu kisas. Ganjaran yang terdapat dalam hudūd memberikan jaminan bahwa proses perlindungan jiwa dalam posisi sangat penting sehingga memungkinkan orang yang membunuh pun hukumannya bisa juga dibunuh. Itulah sebabnya, Alquran mendorong seorang pemimpin negara dalam

\footnotetext{
${ }^{27}$ Kementerian Agama RI, Al-Quran dan Terjemahannya (Jakarta: Dinamika Berkah, 2003). h. 175.

${ }^{28} \mathrm{Ahmad}$ al-Mursi Husain Jauhar, Maqūṣid al-Syarī'at Fì al-Islām, terj. oleh Khikmawati dengan judul Maqashid Syariah (Jakarta: AMZAH, Cet. I, 2009), h. 4.

${ }^{29}$ Kementerian Agama RI..., h. 154.
} 
mewujudkan kemashlahatan jiwa, agar memperhatikan perintah Allah Swt., yang memerintahkan manusia untuk menikah secara syar'i dan melarang manusia untuk membunuh karena hal tersebut akan mencederai jiwa manusia, sebagaimana firman Allah dalam QS. al-An'am/6: 151:

Terjemahnya:

$$
\text { ولا تقتلوا النفس التى حرم الله إلا بالحق }
$$

“...Janganlah kamu melakukan pembunuhan terhadap diri yang diharamkan Allah, kecuali secara hak." 30

Demikian pula dengan menjaga dan melindungi akal, seorang pemimpin negara harus menjamin keselamatan akal masyarakat oleh karena dalam Islam akal itu menempati posisi yang sangat eksklusif sehingga untuk kondisi tertentu, agama tidak memiliki yurisdiksi menerapkan hukum atas akal. Itulah sebabnya, dalam kondisi seseorang menjadi gila misalnya, maka perbuatan hukumnya tidak dapat dinilai, bahkan seseorang yang belum mencapai kematangan dalam akal (akil balig), maka hukum menyatakan bahwa orang seperti ini tidak memiliki kecakapan dalam perbuatan hukumnya. Kondisi serupa berlaku pada seseorang yang karena kondisi tertentu di mana akalnya tidak berfungsi seperti tidur, maka ia tidak memiliki yurisdiksi untuk melaksanakan atau kewajibannya menjadi gugur. Inilah yang melandasi hukum Islam sangat agresif untuk melindungi akal karena ia menjadi pangkal utama kecakapan manusia dalam bertindak secara hukum.

Menjadi seorang subjek hukum yang mampu bertindak secara hukum, maka seorang pimimpin negara harus mampu mewujudkan perlindungan terhadap akal dengan memberi jaminan kepada masyarakat untuk memelihara akal yang diciptakan Allah Swt., karenanya setiap orang harus menjaga akalnya dengan mengasah dan meningkatkan kualitasnya akalnya dengan cara menuntut ilmu oleh karena menuntut ilmu itu merupakan perbuatan baik yang diperintahkan Allah.

Akal dan ilmu adalah dua hal yang tidak bisa dipisahkan oleh karena akal akan cemerlang dengan bantuan ilmu dan ilmu akan berkembang dengan bantuan akal. Itulah sebabnya, dalam kata علم itu adab tiga huruf yang memiliki makna yang dalam untuk mengembangkan kebijkan seorang pemimpin terhadap diri sendiri apalagi sebagai pemimpim masyarakat. Pada huruf $\varepsilon$ terbuka mulutnya mengndung makna bahwa seorang manusia harus selalu haus dan lapar untuk mencari ilmu dalam kehidupannya oleh karena ilmu itu yang akan menjadikannya sebagai manusia yang beradab dalam masyarakat. Pada huruf $J$ mengarah ke atas, itu artinya bahwa setiap orang yang mencari ilmu suatu saat akan mendapatkan kedudukan yang tinggi di tengah masyarakat karenanya tidak mengherankan jika para pemimpin negara memiliki kedudukan yang tinggi disebabkan karena ilmu itu sendiri. Huruf menghadap ke bawahp, itu berarti bahwa setiap orang berilmu itu harus rendah hati, agar ilmunya dapat membawa kemaslahatan pada dirinya dan kepada orang lain. Pemimpin-pemimpin negara dan pemimpin masyarakat yang kita saksikan sekarang ini, jika segala kebijakannya diarahkan untuk kepentingan masyarakatnya itu berarti ilmu yang dimilikinya telah membawanya kepada kebijaksanaan yang tinggi, tetapi

${ }^{30}$ Kementerian Agama RI, Al-Qur'an ..., h.117. 
sebaliknya, jika ada pemimpin negara dan pemimpin masyarakat menyalahgunakan ilmunya, maka sesungguhnya ilmu yang dimilikinya tidak memberikan kemaslaahatan kepada dirinya apalagi terhadap orang lain.

Karena itu, dengan mencerdaskan akal melalui proses pencarian dan menuntut ilmu, maka akal akan mampu membedakan mana yang baik dan mana yang buruk

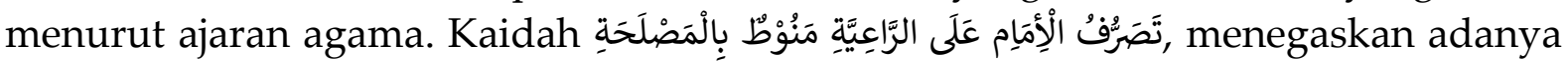
kemaslahatan akal manusian, maka hukum Islam kemudian membatasi kemungkinan-kemungkinan lain yang dapat menyebabkan mukalaf mengalami kerusakan akal. Salah satu di antara hal itu adalah pengharaman narkoba dan psikotrofika. Narkoba dan psikotrofika termasuk turunannya, seperti minuman memabukkan diganjar hukum had oleh Abū Hanifah dan Imam Malik dalam mazhabnya. ${ }^{31}$

Demikian pula dengan perbuatan zina, maka melalui kaidah ini, seorang pemimpin negara harus mampu mengatur agar masyarakat tidak melakukan perzinahan oleh karena dapat merusak nasab seseorang. Atas dasar itu, hukum Islam sangat intens membebani masyarakat agar menghindari perbuatan zina, sehingga dapat dieleminir kesemrawutan dalam struktur keluarga yang tidak jelas karena anak-anak yang lahir dari hasil zina. Pada sisi lain, hukum Islam sangat menganjurkan agar masyarakat berkeluarga dan berketurunan secara normal, sehingga dapat dicapai kemaslahatan manusia dalam hal menjaga dan melindungi keturunan.

Alquran sesungguhnya telah menegaskan agar seorang pemimpin bertanggung jawab untuk menjaga keturunan setiap masyarakatnya oleh karena dalam ajaran agama Islam, Allah Swt., telah memerintahkan untuk menjaga keturunan tersebut melalui pernikahan agar manhsia terhindar dari berbuat zina, karena zina akan merusak keturunan, sebagaimana firman Allah dalam QS. alNur/24: 32:

"Dan kawinkanlah orang-orang yang sendirian di antara kamu, dan orang-orang yang layak (berkawin) dari hamba-hamba sahayamu yang lelaki dan hambahamba sahayamu yang perempuan. Jika mereka miskin Allah akan memampukan mereka dengan kurnia-Nya. Dan Allah Maha luas (pemberianNya) lagi Maha Mengetahui."32

Kemaslahatan terakhir yang harus dilindungi oleh seorang pemimpin negara adalah menjaga perbuatan masyarakat untuk tidak mengadakan transaksi dalam bentuk jual-beli yang dapat menimbulkan mudarat bagi orang lain, oleh karena menjaga dan melindungi aktivitas masyarakat merupakan sebuah wujud kepedulian seorang pemimpin negara dalam melindungi harta rakyatnya dengan melarang manusia mencuri, menghukum orang yang mencuri dan memperbolehkan manusia

\footnotetext{
${ }^{31}$ Defenisi mabuk mendapat pandangan yang beragam oleh para imam mazhab, seperti apa yang dikemukakan oleh Ahmad bin Hanbal bahwa mukalaf itu mabuk jika akalnya berubah dari keadaan ia sehat. Lebih jauh lagi Sufyan al-Ṡaurīy menyatakan bahwa mabuk itu adalah cacatnya akal, jika seseorang yang mabuk diminta untuk membaca bacaan dan bacaanya bercampur aduk atau berucap dan ucapannya mengigau, maka kondisi demikian dinamakan mabuk, Jauhar, Maqasid,...... h. 100 ${ }^{32}$ Kementerian Agama RI, Al-Qur'an ..., h. 282.
} 
untuk bertransaksi secara syar'i. Kebijakan-kebijakn pemimopin seperti ini sesungguhnya sesuai dengan ajaran Islam, sebagaimana firman Allah dalam QS. alJumu'ah/62: 10:

Terjemahnya:

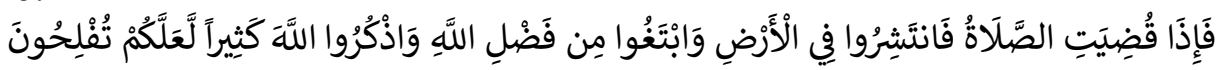

"Apabila telah ditunaikan sembahyang, maka bertebaranlah kamu di muka bumi; dan carilah karunia Allah dan ingatlah Allah banyak-banyak supaya kamu beruntung." 33

Mengacu kepada kelima bentuk kemaslahatan yang tekah diuraikan

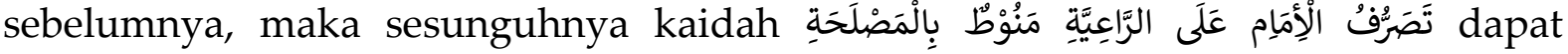
dikatakan bahwa kaidah ini sangat terkait dengan kebijakan seorang pemimpin dalam mengatur kemaslahatan setiap rakyatnya, terutama menyangkut kehidupan orang banyak. Dengan kata lain, kaidah ini memberikan batasan yang pasti terhadap kebijakan seorang pemimpin dalam mengatur segala bentuk kepemimpinan, baik dalam bentuk perintah bagi orang yang memimpin untuk melakukan segala tindakan dengan dasar maslahat yang ingin diraih untuk semua orang yang ada di bawah kepemimpinannya, sekaligus adanya larangan bagi mereka untuk melakukan tindakan yang dapat mendatangkan bahaya atau kerugian bagi orang-orang yang dipimpinnya. Diantara penerapan kaidah ini adalah apa yang telah disebutkan oleh al-Suyuthi dalam al-Asybāh wa al-Nadhāir, diantaranya adalah: ${ }^{34}$

1. Ketika seorang pemimpin membagi harta zakat kepada delapan ashnāf (kelompok) yang merupakan para mustahiq (yang berhak menerima zakat), maka ia tidak boleh mengutamakan salah satu kelompok dari yang lainnya ketika kebutuhan mereka sama.

2. Jika seorang pemimpin hendak memakzulkan sebagian dari tentaranya karena sebab tertentu, maka hal itu diperbolehkan, namun jika tanpa ada sebab yang melatarbelakanginya tidak diperbolehkan.

3. Sebagaimana yang disebutkan oleh al-Mawardi, tidak bolehnya seorang pemimpin mengangkat orang yang fasiq sebagai imam dalam salat, walaupun kami berpendapat tentang sahnya shalat di belakang mereka, karena hal itu hukumnya makruh. Dan seorang pemegang kekuasaan diwajibkan untuk memperhatikan kemaslahatan orang yang dipimpinnya, dan tidak ada maslahatnya ketika ia mengajak kepada hal yang makruh hukumnya.

4. Seorang pemimpin (imam) dilarang membagikan zakat kepada yang berhak (mustahiq) dengan cara membeda-bedakan diantara orang-orang yang tingkat kebutuhannya sama.

5. Seorang pemimpin tidak boleh mendahulukan pembagian harta baitul mal kepada seorang yang kurang membutuhkannya dan mengakhirkan mereka yang lebih membutuhkan.

\footnotetext{
${ }^{33}$ Kementerian Agama RI, Al-Qur'an ..., h. 442.

${ }^{34} \mathrm{Abd}$ al-Rahmān bin Abi Bakr al-Suyūthi, al-Asybāh wa al-Nadzāir (Dār al-Kutub al-Ilmiyah, 1990), h. 121
} 
Di samping contoh di atas, penerapan kaidah ini juga dapat dilihat dalam pengutusan para pengambil harta zakat yang telah dilakukan oleh Rasulullah saw. dan para sahabatnya serta para pemimpin kaum muslimin yang mengikuti jejak mereka. Petugas-petugas zakat yang diangkat Nabi saw. Di antaranya ialah Ibn Lutaibiyah $^{35}$ Abu Mas'ud, Abu Jahem, Uqbah bin Amir, Dhahhak, Ibn Qais dan Ubadah bin Shamit. Petugas zakat tersebut dinamai mushaddiq atau sa'i. Perbuatan Nabi tersebut diteruskan oleh para khalifah empat. ${ }^{36}$

Orang-orang yang diutus untuk mengambil harta zakat oleh Rasulullah saw. yang dikenal dengan al-Su'āh atau al-Jäbi dan para khalifah setelah beliau serta pemimpin kaum muslimin yang mengikuti merekadilandasi oleh kepiawaian mereka sebagai seorang pemimpin yang mampu melihat kemaslahatan yang dibutuhkan oleh orang-orang yang berada di bawah kepemimpinannya sehingga amanah yang telah diterimanya menuntut mereka untuk mengambil kebijakan yang tepat sesuai dengan maslahat yang dibenarkan oleh syari'ah.

Dalam konteks bernegara, maka kaidah ini sangat relevan jika dikaitkan dengan kebijakan seorang kepala negara dalam mengusulkan perundangundangangan. Dalam konteks negara Indonesia, ada banyak kebijakan-kebijakan pemerintah dewasa ini yang mendapatkan penolakan oleh masyarakat disebabkan peraturan perundang-undangan tersebut tidak memihak kepada masyarakat atau dengan kata lain, prodak perundangan-undangan tersebut tidak mewujudkan kemamaslahatan bagi masyarakat secara umum, bahkan sebaliknya, prodak perundang-undangan tersebut lebih memihak kepada kepentingan golongan

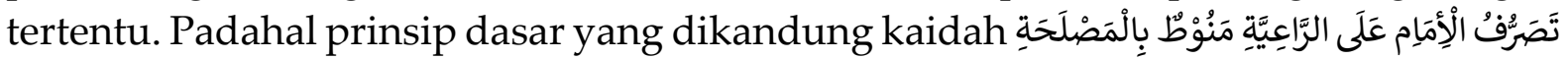
adalah agar setiap kebijakan pemerintah harus berlandaskan dan bernafakan pada kemaslahatan masyarakat umum.

Di antara prodak-prodak perundang-undangan yang banyak menimbulkan pro kontra di masyarakat adalah dikeluarkannya Peraturan Pemerintah Pengganti Undang-undang (Perppu) No. 2 Tahun 2017 yang menegaskan perubahan atas Undang-Undang N0. 17 Tahun 2013 yang membicarakan tentang Organisasi Kemasyarakatan (Ormas). Bentuk penolakan atas Perppu ini dengan diajukannya judical review ke Mahkamah Konstitusi menunjukkan bahwa Perppu ini tidak mengusung kemaslahatan atas kepentingan masyarakat banyak.

Rancangan Undang-Undang (RUU) lainnya yang menimbulkan polemik di masyarakat karena tidak mengedepankan aspek kemaslahatan masyarakat umum adalah Undang-Undang Cipta Kerja atau omnibus law. Undang-undang omnibus law

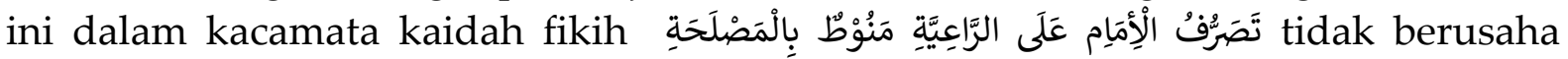
mewujudkan kemaslahatan umum. Karena itu, Undang-Undang omnibus law banyak mendapatkan penentangan di kalangan masyarakat.

\footnotetext{
${ }^{35}$ Ada beberapa sumber yang menyebutnya ibn Lutaibah, ibn Lutaibiyyah, ibn Labinah dan ada pula yang menyebutnya Ibn al-Lutbiyyah. Dan yang lebih masyhur adalah penyebutannya dengan ibn Lutaibiyyah.

${ }^{36}$ M. Hasbi ash-Shiddieqy, Pedoman Zakat (Semarang: Pustaka Rizki Putra, 2009), h. 52.
} 


\section{KESIMPULAN}

Berdasarkan uraian yang telah dikemukakan di atas, maka dalam penelitian ini terdapat tiga poin yang menjadi kesimpulan, yaitu; pertama, Akar kata kaidah

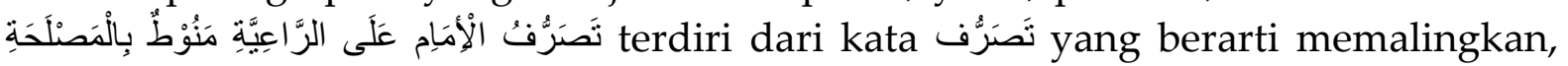

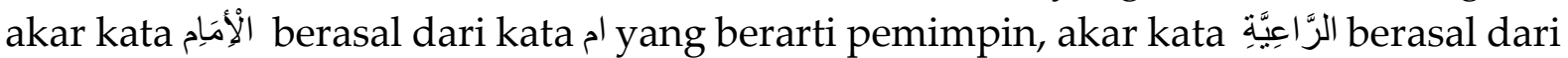

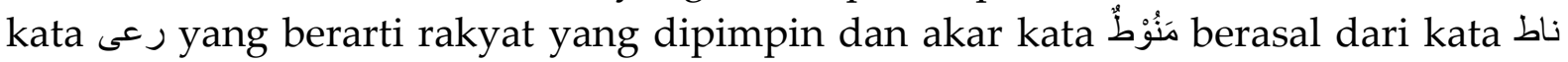

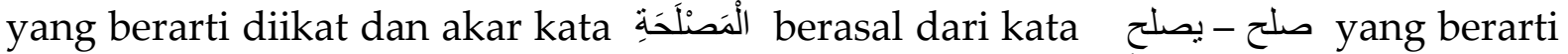

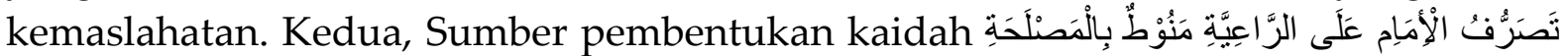

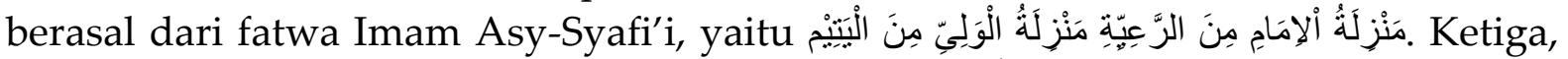

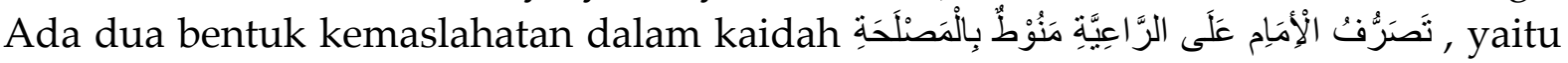
kemaslahatan pokok (ḍarūriyah), dan kemaslahatan (gairu ḍarūriyah).

\section{DAFTAR PUSTAKA}

Abd al-Karīm Zaidān, al-Waj̄̄z f̄̄ Syarh al-Qawā'id al-Fiqhiyyah. Beirūt: Muassasah al-Risālah, 2004.

Abd al-Rahmān bin Abi Bakr al-Suyūthi, al-Asybāh wa al-Nadzāir. Dār al-Kutub alIlmiyah, 1990.

Abd al-Rahman bin Muhammad bin Khaldun, Muqaddimah Ibn Khaldun. Riyādh: Dār 'Alam al-Kutub, 1996.

Al-Anshāri, Zakariyya bin Muhammad. Asnā' al-Mathālib fî Syarh Raudhah al-Thālib Zain al-Dīn Ibrāhīm bin Nujaim, al-Asybāh wa al-Nadhāir

Al-Ghazāli, Muhammad bin Muhammad. al Mustashfā fī Ushūl al-Fiqh. Beirūt: Muassasah al-Risālah, 1997.

al-Hilli, al-Ashbahani, dan al-Qausyaji dalam Kitab Rusydi 'Ulyan, al-Islam wa alKhilafah. Baghdād: Dār al-Salām, 1976.

Ali bin Muhammad bin Muhammad al-Māwardi, al-Ahkām al-Sulthāniyyah. Kairo: Dâr al-Hadīs, tt.

Al-Jurjani, Ali bin Muhammad bin Ali. al-Ta'rīfāt. Beirut: Dār al-Kutub al-Arabi, 1405. Al-Mandzūr, Ibn. Lisān al-'Arab al-Muhith (Beirūt: Dār Lisān al-'Arab, tt)

Al-Quran dan Terjemahannya

Al-Rāzi, Muhammad bin Abi Bakr bin Abd al-Qādir. Mukhtār al-Shihāh. Beirūt: alMaktabah al-'Ashriyyah, 2004.

Al-Syaukāni, Muhammad bin 'Ali. Irsyād al-Fuhūl Ilā Tahqīq al-Haq min 'Ilm alUshūl. Riyādh: Dār al-Fadhīlah, 2000.

Al-Thāhir Ahmad al-Zāwi, Tartīb al-Qāmūs al-Muhīth 'alâ Tharīqat al-Misbāh alMun̄̄r wa Asās al-Balāghah (Riyādh: Dār 'Alam al-Kutub, 1996.

Al-Zāwi, al-Thāhir Ahmad. Tartib al-Qāmūs alMuhīth 'alâ Tharīqat al-Misbāh alMunīr wa Asās al-Balāghah. Riyādh: Dār 'Alam al-Kutub, 1996.

Ash-Shiddieqy, M. Hasbi. Pedoman Zakat. Semarang: Pustaka Rizki Putra, 2009.

Ibrāhīm Anîs, Abd al-Halīm Muntashir, dll., al-Mu'jam al-Wasīth, 1972.

Mudjib, H. Abdul. Kaidah-Kaidah Ilmu Fikih. Jakarta: Kalam Mulia 2005. 
Syarifuddin, Amir Ilmu Ushul Fiqh. Jakarta: Bulan Bintang, 2008. 